\title{
Determination of Mercury in Aerosol by Inductively Coupled Plasma Mass Spectrometry *
}

\author{
by \\ Iris Hofer, Maude Gremaud, Audrey Marchese, and Soazig Le Bouhellec
}

Philip Morris International R\&D, Philip Morris Product SA, Quai Jeanrenaud 5, 2000 Neuchâtel, Switzerland

\section{SUMMARY}

Based on the knowledge gained from published studies, a new analytical method has been developed for the quantification of mercury $(\mathrm{Hg})$ in the gas-vapor phase of mainstream cigarette smoke and in heated tobacco aerosol generated by a tobacco heating system (THS) using Inductively Coupled Plasma Mass Spectrometry (ICP-MS). From a preliminary test, the mercury concentration in the particulate matter of mainstream smoke from Kentucky reference cigarettes 3R4F generated under the International Organization for Standardization (ISO) smoking regimen was compared with the mercury concentration in the gasvapor phase to assure that mercury is only measurable in the gas-vapor phase, as reported in an earlier published study. The particulate matter was collected using an electrostatic precipitation trap and was analyzed by ICPMS after a mineralization step. The gas-vapor phase was trapped in the same smoking run as for the particulate matter using two impingers containing a nitric acid-hydrochloric acid-gold solution. The impingers were connected in series behind the electrostatic precipitation trap and the combined impinger solution was analyzed by ICP-MS after sample dilution without further sample treatment. The addition of gold has shown to be efficient for maintaining mercury in an ionized form in the impinger solution and to minimize the mercury memory effect in the sample introduction system of the ICP-MS. Only mercury in the gasvapor phase could be quantified whereas the signal for mercury in the particulate matter was found close to those of blank solutions and was not measurable, as already mentioned in an earlier study. Following this preliminary test, the electrostatic precipitation trap was replaced by a Cambridge filter pad for the separation of the gas-vapor phase from the particulate matter where only mercury in the gas-vapor phase was quantified.

The method for the quantification of mercury in the gasvapor phase of aerosols obtained under Health Canada (HC) and ISO smoking regimens was validated according to International Conference on Harmonisation of Technical Requirements for Registration of Pharmaceuticals for Human Use (ICH) and Association of Official Analytical Chemists (AOAC) guidelines. Accuracy profiles were evaluated as described in Association Française de Normalisation (AFNOR). The regression curve was shown to be linear within the evaluated concentration range from $25 \mathrm{pg} / \mathrm{mL}$ to $1000 \mathrm{pg} / \mathrm{mL}$ with a weighting factor $1 / \mathrm{x}$. The coefficients of variation for repeatability (r) were $3.6 \%$ for $3 \mathrm{R} 4 \mathrm{~F}$ and $4.8 \%$ for THS under HC smoking regimen and $3.6 \%$ for $3 \mathrm{R} 4 \mathrm{~F}$ and $4.6 \%$ for THS under ISO smoking regimen. The coefficients of variation for intermediate precision (IP) were $7.7 \%$ for $3 \mathrm{R} 4 \mathrm{~F}$ and $7.7 \%$ for THS under $\mathrm{HC}$ smoking regimen and $4.7 \%$ for $3 \mathrm{R} 4 \mathrm{~F}$ and $4.6 \%$ for THS under ISO smoking regimen. The nominal mercury concentrations for $3 \mathrm{R} 4 \mathrm{~F}$ obtained during the validation under both HC and ISO smoking regimens were found to be in line with results reported in a previously published CORESTA study. [Beitr. Tabakforsch. Int. 27 (2017) 186-194] 


\section{ZUSAMMENFASSUNG}

Basierend auf den Erkenntnissen von veröffentlichten Studien wurde eine neue Methode zur Quantifizierung von Quecksilber (Hg) in der Gasdampf-Phase von Zigarettenhauptstromrauch und im Aerosol eines in einem TabakHeizsystem (THS) erhitzten Tabaks mittels Massenspektrometrie mit induktiv-gekoppeltem-Plasma (ICP-MS) entwickelt.

Bei einem ersten Test wurde der Quecksilbergehalt von Kentucky 3R4F Testzigaretten in der Partikelphase unter Maschinenrauchbedingungen, entsprechend der Internationalen Organisation für Normung (ISO) bestimmt und mit dem Quecksilbergehalt in der Gasdampf-Phase verglichen, um sich zu vergewissern, dass Quecksilber nur in der Gasdampf-Phase messbar ist, wie es in einer früheren veröffentlichten Studie erwähnt wurde. Die Partikelphase wurde mittels einer elektrostatischen Niederschlag-Falle erfasst und nach der Mineralisierung mittels ICP-MS analysiert. Die Gasdampf-Phase wurde zur gleichen Zeit mit der Partikelphase in zwei mit Salpetersäure-SalzsäureGold-Lösung gefüllten Gaswaschflaschen gesammelt und nach Probenverdünnungen ohne weitere Aufbereitung mittels ICP-MS analysiert. Die Goldzugabe in der Salpetersäure hatte sich als wirksam erwiesen, das Quecksilber in seiner ionisierter Form in der Säurelösung zu erhalten und somit den Quecksilber-Memory-Effekt in dem Einführungssystem des ICP-MS zu verringern. Quecksilber konnte nur in der Gasdampf-Phase erfasst werden, da sich das Quecksilbersignal der Partikelphase in der Größenordnung der Reinproben befand und damit nicht quantifizierbar war, wie bereits in einer früheren Studie erwähnt wurde. Anschliessend dieser ersten Teste wurde die elektrostatische Niederschlag-Falle für die Trennung der Gasdampf-Phase von der Partikelphase durch einen Cambridge-Filter ersetzt, wobei Quecksilber nur in der Gasdampf-Phase gemessen wurde. Die Methode für die Quecksilberbestimmung in der Gasdampf-Phase im erzeugten Aerosol unter Health Canada (HC)- und ISO-Maschinenrauchbedingungen wurde entsprechend der International Conference on Harmonisation of Technical Requirements for Registration of Pharmaceuticals for Human Use (ICH) und der Association of Official Analytical Chemists (AOAC) Richtlinien validiert. Genauigkeitsprofile wurden nach Angaben von Association Française de Normalisation (AFNOR) durchgeführt. Die Methode erwies sich als linear innerhalb des ausgewerteten Konzentrationbereichs von $25 \mathrm{p} \mathrm{g} / \mathrm{mL}$ bis $1000 \mathrm{pg} / \mathrm{mL}$ mit einem Gewichtungsfaktor von $1 / x$. Es wurden Variationskoeffizienten für die Wiederholgenauigkeit (r) von $3.6 \%$ für 3R4F und $4.8 \%$ für THS unter HC-Maschinenrauchbedingungen und $3.6 \%$ für $3 \mathrm{R} 4 \mathrm{~F}$ und $4.6 \%$ für THS unter ISO-Maschinenrauchbedingungen gefunden. Für die Variationskoeffizienten der Präzision (IP) wurden 7.7\% für 3R4F und 7.7\% für THS unter HC-Maschinenrauchbedingungen und $4.7 \%$ für 3R4F and $4.6 \%$ für THS unter ISO-Maschinenrauchbedingungen ermittelt. Die Resultate der Methodenvalidierung des gemessenen Quecksilbergehalts im erzeugten 3R4F-Hauptstromrauch mit Health Canada- und ISO-Maschinenrauchbedingungen sind vergleichbar mit veröffentlichten Resultaten einer CORESTA-Studie. [Beitr. Tabakforsch. Int. 27 (2017) 186-194]

\section{RESUME}

Se basant sur les connaissances acquises par des études publiées, une nouvelle méthode pour la quantification de mercure $(\mathrm{Hg})$ dans la phase gazeuse du flux principal de la fumée de cigarette et dans l'aérosol d'un dispositif de tabac chauffé (THS) a été développée en utilisant la spectrométrie de masse à plasma à couplage inductif (ICP-MS).

D'un test préliminaire, la teneur en mercure dans la matière particulaire du flux principal de la fumée de cigarette de référence Kentucky $3 \mathrm{R} 4 \mathrm{~F}$, générée avec le régime de fumage d'Organisation internationale de normalisation (ISO), a été évaluée et comparée avec la teneur en mercure dans la phase gaz-vapeur pour s'assurer que le mercure est seulement mesurable dans la phase gaz-vapeur comme décrit dans une étude publiée précédemment. La matière particulaire a été collectée à l'aide d'un piège de précipitation électrostatique et a été analysée par ICP-MS après la minéralisation de la solution. Avec la matière particulaire, la phase gaz-vapeur a été retenue dans deux flacons laveurs contenant une solution d'acide nitrique-acide chlorhydrique-or, connectés en série derrière un piège de précipitions électrostatique et a été analysée après dilution de l'échantillon par ICP-MS sans traitement supplémentaire. L'addition de l'or a démontré son efficacité à garder le mercure sous sa forme ionisé dans la solution d'acide nitrique et à minimiser l'effet mémoire du mercure dans le système d'introduction de l'échantillon de l'ICP-MS. Le mercure n'a seulement pu être quantifié que dans la phase gaz-vapeur tandis que le signal du mercure dans la matière particulaire avait été trouvé proche de celui des blancs, c'est-à-dire plus détectable, comme reporté dans une étude précédente. Suite aux tests préliminaires, le piège de précipitation électrostatique a été remplacé par un filtre Cambridge pour la séparation de la phase gazeuse de la matière particulaire où seulement le mercure dans la phase gazeuse a été quantifié.

La méthode pour la quantification du mercure dans la phase gaz-vapeur de l'aérosol, généré avec le régime de fumage Health Canada (HC) et ISO, a été validée selon les directives de l'International Conference on Harmonisation of Technical Requirements for Registration of Pharmaceuticals for Human Use (ICH) et de l'Association of Official Analytical Chemists (AOAC). Les profils d'exactitude ont été réalisés comme décrit dans l'Association Française de Normalisation (AFNOR). La méthode s'est avérée être linéaire dans la plage de concentration évaluée de $25 \mathrm{pg} / \mathrm{mL}$ à $1000 \mathrm{pg} / \mathrm{mL}$ avec un facteur de pondération de $1 / \mathrm{x}$. Les coefficients de variation de répétabilité (r) étaient de $3.6 \%$ pour $3 \mathrm{R} 4 \mathrm{~F}$ et $4.8 \%$ pour le THS sous le régime de fumage $\mathrm{HC}$ et $3.6 \%$ pour $3 \mathrm{R} 4 \mathrm{~F}$ et $4.6 \%$ pour les THS sous ISO. Les coefficients de variation pour la précision intermédiaire (IP) étaient de $7,7 \%$ pour $3 \mathrm{R} 4 \mathrm{~F}$ et $7,7 \%$ pour le THS sous le régime de fumage $\mathrm{HC}$ et $4,7 \%$ pour $3 \mathrm{R} 4 \mathrm{~F}$ et $4,6 \%$ pour les THS sous ISO. Les résultats de mercure pour la $3 \mathrm{R} 4 \mathrm{~F}$, obtenus lors de la validation de la méthode en régimes de fumage $\mathrm{HC}$ et ISO, sont en accord avec les résultats reportés dans une étude de CORESTA. [Beitr. Tabakforsch. Int. 27 (2017) 186-194] 


\section{INTRODUCTION}

Mercury $(\mathrm{Hg})$ is a well-known environmental contaminant and is one of the 93 compounds in mainstream cigarette smoke which are classified as harmful and potentially harmful by the Food and Drug Administration (FDA) (6). Both, cigarette mainstream smoke and aerosol of THS are combinations of their respective gas-vapor and particulate matter phases. The gas-vapor phase contains volatile compounds such as carbon monoxide, carbon dioxide, nitrous oxides etc., whereas the particulate matter comprises less volatile compounds such as nicotine, humectants, tobacco-specific nitrosamines (TSNAs), phenols, metals and many other constituents.

Only a few studies have investigated the mercury concentration of tobacco, and even fewer have been conducted in the field of gas-vapor and particulate matter phases of mainstream smoke, due to the complexity of measurement. Mercury is present in trace levels in mainstream smoke and its detection requires both, sensitive and selective instrumentation. In the past, the measurement of mercury was mainly performed using Cold Vapor Atomic Absorption Spectrometry (CVAAS) $(1,7)$, Cold Vapor Atomic Fluorescence Spectroscopy (CVAFS) (10) or a mercury analyzer (8). These techniques are specific for mercury analysis. The use of ICP-MS was discounted due to the memory effect of mercury within the sample introduction system, requiring long washout times which generated unreliable results for mercury. Several studies have shown that the mercury-memory effect can be dramatically decreased when gold is added to nitric acid $\left(\mathrm{HNO}_{3}\right)$ solutions (9-11). In 2003, the US Environmental Protection Agency (EPA) published a bulletin (12) reporting the use of gold chloride to stabilize mercury in solution, which enables the use of ICP-MS, as described in the EPA method 6020A (13) for the quantification of mercury in water samples, waste extracts or digests. Furthermore, British American Tobacco established a method using ICP-MS for the quantification of mercury in mainstream smoke trapped by impingers (14).

Moreover, the high volatility of mercury has to be taken into account for the aerosol collection and the mineralization steps in order to ensure a sensitive and selective technique for the analysis of mercury. Based on the knowledge gained from published studies, a new analytical method has been developed for the quantification of mercury in the gas-vapor phase of mainstream cigarette smoke and in heated tobacco aerosol generated by the tobacco heating system (THS) (15) by ICP-MS, without time-consuming mineralization steps. The gas-vapor phase is collected using two impingers containing a nitric acidhydrochloric acid-gold solution with indium (In) as Internal Standard (IS) which are connected in series behind a Cambridge filter pad and the mouthpiece of the smoking machine. The combined impinger solution is analyzed by ICP-MS after dilution without further sample treatment.

In a preliminary study, the mercury concentration in the particulate phase of mainstream smoke from 3R4F cigarettes generated under the International Organization for Standardization(ISO) smoking regimen was compared with the mercury present in the gas vapor phase. Only mercury in the gas-vapor phase was quantifiable, whereas the ICP-
MS signals for mercury in the particulate phase were found below the quantification limit, similar to those of blank solutions ( $24 \mathrm{cps}$ ), which confirmed that only the gas-vapor phase needs to be analyzed, as shown in a previous study (1).

\section{EXPERIMENTAL}

\section{Materials}

Nitric acid (purity $65 \%$ Suprapur), mercury ICP standard solution $(1000 \mathrm{mg} / \mathrm{L})$, gold ICP standard solution (1000 mg/L), indium ICP standard solution $(1000 \mathrm{mg} / \mathrm{L})$ were purchased from Merck (Darmstadt, Germany), hydrogen peroxide $\left(\mathrm{H}_{2} \mathrm{O}_{2}\right.$; purity $30 \%$ Trace Select Ultra), sodium bicarbonate (purity 99.5\%) from Sigma Aldrich (Saint Louis, MO, USA), hydrochloric acid (purity 30\% Trace Select Ultra) from Fluka (Saint Louis, MO, USA), MilliQ water (purity > 18.2 M 2 ), argon (purity 99.999\%) from Carbagas (Gümligen, BE, Switzerland), 50-mL and $15-\mathrm{mL}$ polypropylene (PP) volumetric vials from Perkin Elmer (Schwerzenbach, ZH, Switzerland), as well as 30-mL impingers without frit, $150-\mathrm{mL}$ impingers with frit and $250-\mathrm{mL}$ impingers without frit, and $44-\mathrm{mm}$ glass fiber Cambridge filter pads.

The reference cigarettes (3R4F) were obtained from the University of Kentucky (16) and were conditioned for $48 \mathrm{~h}$ under controlled conditions $\left(22 \pm 1{ }^{\circ} \mathrm{C}\right.$; relative humidity $60 \pm 3 \%$ ) prior to aerosol generation; THS heatsticks were taken from a production batch and conditioned in the same way as $3 \mathrm{R} 4 \mathrm{~F}$ cigarettes.

\section{Preparation of standards}

An internal standard (ISTD) solution containing $1 \mu \mathrm{g} / \mathrm{mL}$ of indium was prepared by pipetting $50 \mu \mathrm{L}$ of the indium ICP standard solution $(1000 \mathrm{mg} / \mathrm{L})$ into a $50-\mathrm{mL}$ polypropylene volumetric flask. The flask was made up to volume with a $2 \%$ nitric acid solution.

An initial mercury stock solution containing $16.7 \mu \mathrm{g} / \mathrm{mL}$ mercury was prepared by pipetting $250 \mu \mathrm{L}$ of the mercury ICP standard solution $(1000 \mathrm{mg} / \mathrm{L})$ into a $15-\mathrm{mL}$ polypropylene volumetric flask. The flask was made up to volume with a $2 \%$ nitric acid solution. An intermediate mercury stock solution containing $25,000 \mathrm{pg} / \mathrm{mL}$ of mercury for the preparation of working standards was prepared by diluting $75 \mu \mathrm{L}$ of the initial mercury stock solution $(16.7 \mu \mathrm{g} / \mathrm{mL})$ with a $2 \%$ nitric acid solution into a $50-\mathrm{mL}$ polypropylene volumetric flask.

Standards used for the calibration curve were prepared by pipetting the volumes of the intermediate mercury stock solution $(25,000 \mathrm{pg} / \mathrm{mL})$, the extraction solution and the gold ICP standard solution $(1000 \mathrm{mg} / \mathrm{L})$ into $50-\mathrm{mL}$ polypropylene volumetric flasks, as shown in Table 1.

\section{Extraction solution}

$840 \mathrm{~mL}$ nitric acid (65\%) and $20 \mathrm{~mL}$ hydrochloric acid $(30 \%)$ were carefully added to $140 \mathrm{~mL}$ water. The internal standard and gold were added to this solution by pipetting $0.2 \mathrm{~mL}$ of an internal standard solution containing $1 \mu \mathrm{g} / \mathrm{mL}$ of indium and $1 \mathrm{~mL}$ of the gold ICP standard solution 
Table 1. Preparation of standard solutions for the calibration curve.

\begin{tabular}{l|c|c|c|c|c}
\hline Standard & $\begin{array}{c}\text { Intermediate stock } \\
\text { Hg-solution } \\
(\mu \mathrm{L})\end{array}$ & $\begin{array}{c}\text { Extraction solution } \\
(\mathrm{mL})\end{array}$ & $\begin{array}{c}\text { Gold ICP standard } \\
\text { solution at 1000 mg/L } \\
(\mu \mathrm{L})\end{array}$ & $\begin{array}{c}\text { Final volume } \\
(\mathrm{mL})\end{array}$ & $\begin{array}{c}\text { Concentration for Hg } \\
(\mathrm{pg} / \mathrm{mL})\end{array}$ \\
\hline 0 & - & 7.5 & 50 & 50 & - \\
1 & 50 & 7.5 & 50 & 50 & 25 \\
2 & 100 & 7.5 & 50 & 50 & 50 \\
3 & 200 & 7.5 & 50 & 50 & 100 \\
4 & 500 & 7.5 & 50 & 50 & 250 \\
5 & 1000 & 7.5 & 50 & 50 & 500 \\
6 & 2000 & 7.5 & 50 & 50 & 1000 \\
\hline
\end{tabular}

(1000 mg/L). The same extraction solution for standard preparation and aerosol collection was used. The extraction solution was stable at room temperature for up to 34 days.

\section{Aerosol collection}

3R4F cigarettes and THS items were smoked under HC and/or ISO smoking regimen conditions, using a rotary smoking machine. The number of accumulated items per replicate was 10 for $3 \mathrm{R} 4 \mathrm{~F}$ under $\mathrm{HC}$ and ISO smoking regimen, and 10 and 20 for THS under HC and ISO smoking regimens, respectively. Smoked blanks were generated before generating the mainstream smoke of $3 \mathrm{R} 4 \mathrm{~F}$ or the aerosol of THS.

Particulate matter of the mainstream smoke of 3R4F and aerosol of THS was retained on a 44-mm glass fiber Cambridge filter pad and the gas-vapor phase trapped using a $150-\mathrm{mL}$ impinger containing $20 \mathrm{~mL}$ extraction solution and $2 \mathrm{~mL} \mathrm{H}_{2} \mathrm{O}_{2}$ (30\%) followed by a $30-\mathrm{mL}$ impinger containing $10 \mathrm{~mL}$ extraction solution and $1 \mathrm{~mL} \mathrm{H}_{2} \mathrm{O}_{2}(30 \%)$ $\left(\mathrm{H}_{2} \mathrm{O}_{2}(30 \%)\right.$ is added to the impinger solution just before the smoking run). Impingers intended to collect the aerosol were connected as close as possible behind the Cambridge filter pad to avoid excessive dead volume; as required, a lift platform was used to reduce the connection length between impingers and Cambridge filter pad. In addition to the impingers for aerosol collection, a third, larger impinger $(250 \mathrm{~mL})$ containing approximately $100 \mathrm{~mL}$ saturated sodium bicarbonate solution was connected before the smoking pump to provide protection against acidic vapors. The third impinger was only changed once the $\mathrm{pH}$ fell below 7 .

\section{Sample preparation procedure}

After aerosol collection, $5 \mathrm{~mL}$ of the gas-vapor phase extract of the first impinger and $2.5 \mathrm{~mL}$ of the second impinger were transferred into a $50-\mathrm{mL}$ volumetric flask, to which $50 \mu \mathrm{L}$ of the gold ICP standard solution $(1000 \mathrm{mg} / \mathrm{L})$ was added prior to making up to volume with water. The Cambridge filter pad containing the particulate matter was discarded since no mercury could be quantified in the particulate phase in preliminary experiments.

\section{ICP-MS analysis}

Analyses were performed using an Agilent 7700 ICP-MS instrument using MassHunter software for data acquisition and treatment (Agilent, Tokyo, Japan). The system was equipped with an integrated auto-sampler a Peltier cooled sample introduction system, a recirculator (Chiller) PolyScience, a peristaltic pump, a MicroMist nebulizer and a quartz spray chamber.

Instrumental parameters for the Agilent ICP-MS system used for mercury analysis are detailed in Table 2.

Table 2. Some instrumental parameters for the quantification of mercury by ICP-MS.

Sample introduction settings

\begin{tabular}{lc}
\hline $\begin{array}{l}\text { Spray chamber } \\
\text { temperature }\end{array}$ & $2{ }^{\circ} \mathrm{C}$ \\
Carrier gas flow & $\sim 1.05 \mathrm{~L} / \mathrm{min}$, optimized daily with the \\
auto-tune \\
Nebulizer pump speed & $0.10 \mathrm{rps}$ \\
$\begin{array}{l}\text { ICP Radio-Frequency } \\
\text { (RF) power }\end{array}$ & $\sim 1550 \mathrm{~W}$ \\
Plasma gas flow & $\sim 15 \mathrm{~L} / \mathrm{min}$ \\
Cones & Platinum, $\varnothing 0.9$ and $1.1 \mathrm{~mm}$ \\
Tune file & No gas \\
Stabilization time & $30 \mathrm{sec}$ \\
Repetition & 3 \\
Acquisition time & $43 \mathrm{sec}$ \\
Mass $\mathrm{m} / \mathrm{z}$ elements & $201 \mathrm{Hg} \quad 200 \mathrm{Hg} \quad 202 \mathrm{Hg} \quad 115 \mathrm{ln}$ \\
& Quantifier Qualifier Qualifier $\quad$ ISTD \\
\hline
\end{tabular}

\section{RESULTS AND DISCUSSION}

The method for the quantification of mercury in the gasvapor phase of mainstream smoke or aerosol generated under both Health Canada (HC) and ISO regimens was validated according to ICH guidelines (3) and AOAC official methods of analysis (4), and accuracy profiles were defined as described by AFNOR (5). Selectivity, linearity of the response function, stability of samples and standard solutions, instrumental limit of detection, lower limit of 
quantification, instrumental repeatability, repeatability limit (r), intermediate precision limit (IP), bias of spiked samples, lower and upper working range for samples and bias versus reference data were evaluated throughout the validation.

Selectivity for mercury was tested in the extraction solution (blank) where the mercury response was compared with the mercury response for the lowest standard level. The response for mercury in blanks was found to be slightly higher than the acceptance threshold (selectivity for mercury in blank was 0.23 , acceptance threshold 0.20 , as depicted in Figure 1). However, it was demonstrated that this had no impact on mercury quantification throughout the validation, since the signal was constant and was considered in the intercept of the calibration curve. Thus the method was considered to be selective. Selectivity was also demonstrated for the internal standard indium in blank, 3R4F and THS matrices (Figure 2).

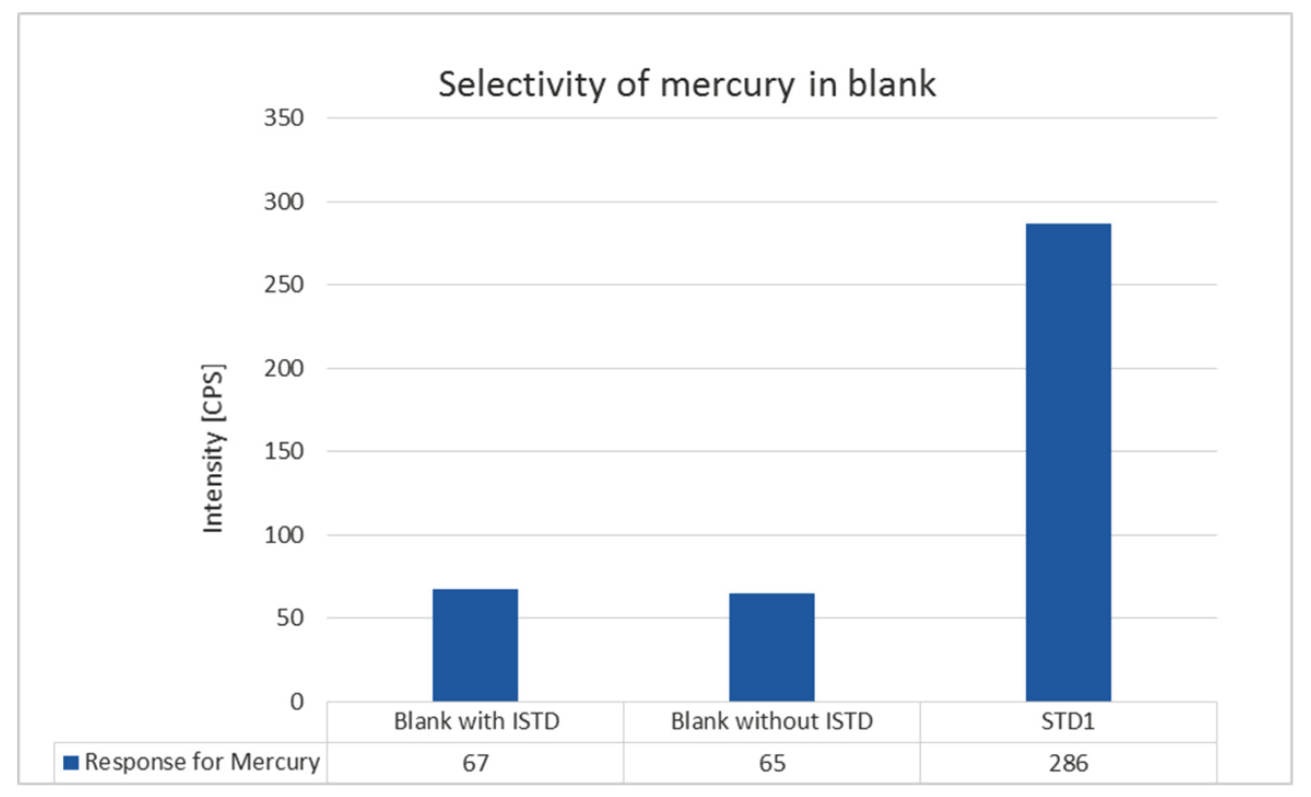

Figure 1. Selectivity of mercury in blank compared to the lowest standard level.

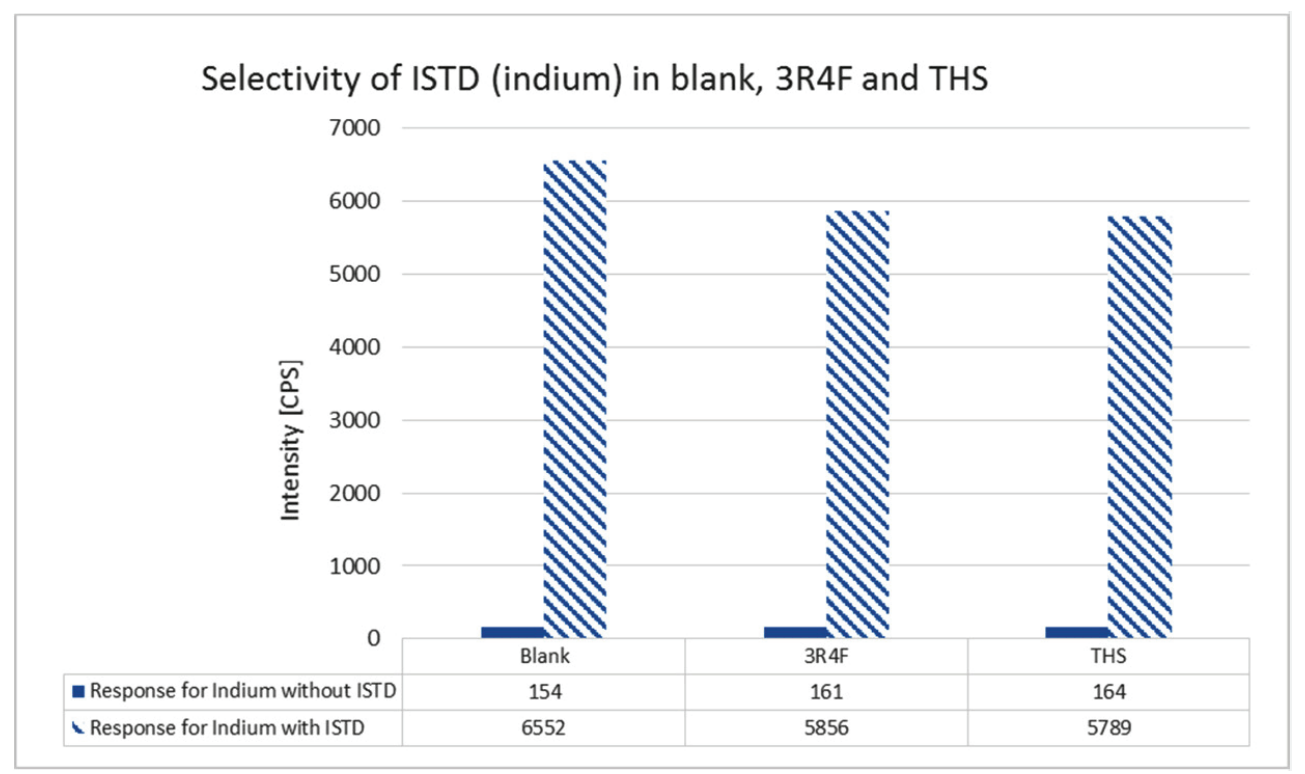

Figure 2. Selectivity of ISTD (indium) in blank, 3R4F and THS. 


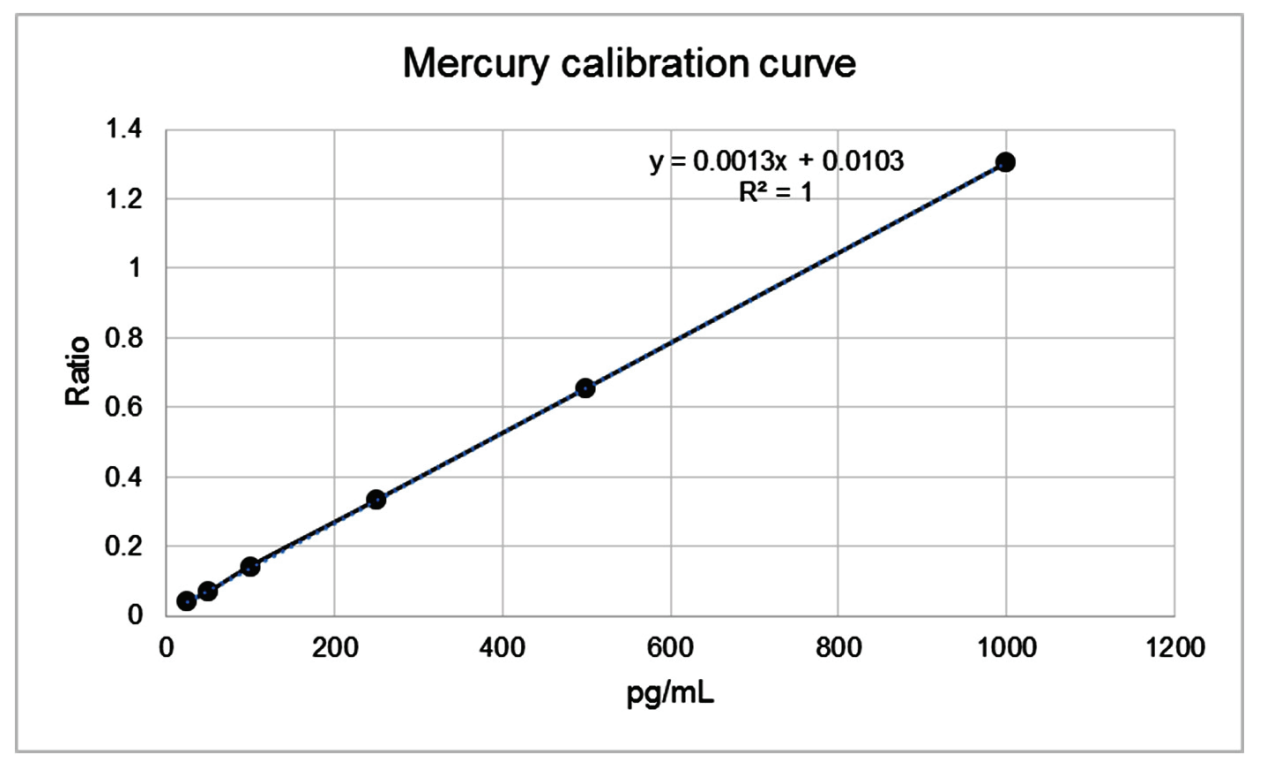

Figure 3. The concentration range in the calibration curve for mercury from $25 \mathrm{pg} / \mathrm{mL}$ to $1000 \mathrm{pg} / \mathrm{mL}$ showed to be linear with a weighting factor $1 / x$.

The linearity of the response function was investigated under intermediate precision conditions by injecting the whole calibration curve over 5 different days. Standard solutions were freshly prepared on each day by a different operator. Based on the calculated residuals, a linear regression with a weighting factor of $1 / \mathrm{x}$ was selected for the quantification of mercury over a calibration range from $25 \mathrm{pg} / \mathrm{mL}$ to $1000 \mathrm{pg} / \mathrm{mL}$.

Extraction solution containing internal standard (indium) stored at room temperature was found to be stable for up to 34 days. The internal standard solution, the intermediate mercury stock solution, working standard solutions and gas-vapor phase extracts for 3R4F and THS were found to be stable for up to 34 days stored refrigerated at $4{ }^{\circ} \mathrm{C}$. Gasvapor phase extracts for $3 \mathrm{R} 4 \mathrm{~F}$ and THS were found to be stable for up to 24 hours at room temperature stored on the auto-sampler.

Lower limits of detection and lower limits of quantification were calculated based on the standard deviation of the lowest calibration standard solution and were found to be lower than the concentration of the lowest calibration standard in the calibration curve (Figure 3 ).

Instrumental repeatability was determined by analyzing ten injections from the same solution. The instrumental repeatability was found to be good with coefficients of variation of $2.0 \%$ for $3 \mathrm{R} 4 \mathrm{~F}$ and $4.5 \%$ for THS. These results demonstrate that a single analytical injection per smoking replicate is sufficient.

The repeatability limit $r$ and the intermediate precision limit IP were evaluated at nominal concentrations. Four individual replicates were performed for 3R4F and THS matrices under $\mathrm{HC}$ smoking regimen over four different days and under ISO smoking regimen over three different days. These validation parameter results include all process variability (aerosol collection and product variability, sample preparation and ICP-MS analysis). Coefficients of variation for repeatability were $3.6 \%$ for $3 \mathrm{R} 4 \mathrm{~F}$ and $4.8 \%$ for THS under Health Canada smoking regimen and 3.6\% for $3 \mathrm{R} 4 \mathrm{~F}$ and $4.6 \%$ for THS under ISO smoking regimen. Coefficients of variation for intermediate precision were $7.7 \%$ for $3 \mathrm{R} 4 \mathrm{~F}$ and $7.7 \%$ for THS under Health Canada smoking regimen and $4.7 \%$ for $3 \mathrm{R} 4 \mathrm{~F}$ and $4.6 \%$ for $\mathrm{THS}$ under ISO smoking regimen.

Recoveries, lower and upper working range limits in $3 \mathrm{R} 4 \mathrm{~F}$ and THS matrices were determined using the accuracy profile methodology as described in the AFNOR standard (5) using homogenized, diluted and mercury-spiked samples. For 3R4F and THS, four smoking days under Health Canada smoking regimen were performed and four individual smoking replicates were generated per day. Homogenized aerosol solutions per matrix were prepared from the four individual smoking replicates generated each day and then dilutions and spikes were applied. Each solution (homogenized solution, homogenized diluted solution and homogenized spiked solution) was analyzed four times. According to Tables 3 and 4, recoveries for mercury spiked samples were found to be greater than $98 \%$ for both matrices and nominal concentrations of mercury for $3 \mathrm{R} 4 \mathrm{~F}$ and THS obtained under $\mathrm{HC}$ and ISO smoking regimens were found within the lower working range limits (LWRL) and upper working range limits (UWRL) (in $\mathrm{pg} / \mathrm{mL}$ ) (Figures 4 and 5).

Results of mercury obtained throughout the validation were compared to data available in the document "Analysis of Reference Cigarette Smoke Yield Data from 21 Laboratories for 28 Selected Analytes as a Guide to Selection of New CORESTA Recommended Methods" (2). In this study, eight laboratories for Health Canada smoking regimen and seven laboratories for ISO smoking regimen shared their data using in-house methodologies for the quantification of mercury for $3 \mathrm{R} 4 \mathrm{~F}$ from where results are presented in Table 5. The nominal concentrations of mercury for 3R4F obtained during the validation under Health Canada and ISO smoking regimens were in line with CORESTA's published results from this study (2) as depicted in Table 5. 
Table 3. Recovery and working range limits for mercury in 3R4F cigarette smoke.

\begin{tabular}{|c|c|c|c|c|c|c|c|c|}
\hline $\begin{array}{l}\text { Mercury I } \\
\text { 3R4F }\end{array}$ & Repetition & $\begin{array}{c}\text { Theoretical } \\
\text { concentration }\end{array}$ & $\begin{array}{c}\text { Measured } \\
\text { concentration }\end{array}$ & $\begin{array}{c}\text { Theoretical } \\
\text { concentration }\end{array}$ & $\begin{array}{c}\text { Measured } \\
\text { concentration }\end{array}$ & Recovery & \multicolumn{2}{|c|}{$95 \%$ Tolerance interval } \\
\hline Level & $(\mathrm{N})$ & $(\mathrm{pg} / \mathrm{mL})$ & $(\mathrm{pg} / \mathrm{mL})$ & (ng / cig) & (ng / cig) & $(\%)$ & $\begin{array}{l}\text { Lower limit } \\
(\%)\end{array}$ & $\begin{array}{l}\text { Upper limit } \\
(\%)\end{array}$ \\
\hline DIL1 & 16 & 46.50 & 47.73 & 0.93 & 0.95 & NA & 91.6 & 113.7 \\
\hline DIL2 & 16 & 116.25 & 118.37 & 2.33 & 2.37 & NA & 93.8 & 109.9 \\
\hline SPO & 16 & 232.50 & 232.50 & 4.65 & 4.65 & NA & 92.6 & 107.4 \\
\hline SP1 & 16 & 282.45 & 281.76 & 5.65 & 5.64 & 99.75 & 90.9 & 108.6 \\
\hline SP2 & 16 & 482.25 & 481.75 & 9.65 & 9.63 & 99.90 & 89.6 & 110.2 \\
\hline SP3 & 16 & 732.00 & 728.85 & 14.64 & 14.58 & 99.57 & 91.7 & 107.5 \\
\hline \multicolumn{3}{|c|}{ Matrix HC (10 acc.) } & 223.33 & & 4.47 & & & \\
\hline & \multicolumn{2}{|c|}{ Matrix ISO (10 acc.) } & 99.25 & & 1.99 & & & \\
\hline & \multicolumn{2}{|c|}{ LWRL (10 acc.) } & 46.50 & & 0.93 & & & \\
\hline & \multicolumn{2}{|c|}{ UWRL (10 acc.) } & 732.00 & & 14.64 & & & \\
\hline
\end{tabular}

DIL1: dilution 1, DIL2: dilution 2, SP0: matrix at nominal concentration, SP1: spike 1, SP2: spike 2, SP3: spike 3

10 acc.: 10 accumulated items per smoking run, LWRL: lower working range limit, UWRL: upper working range limit

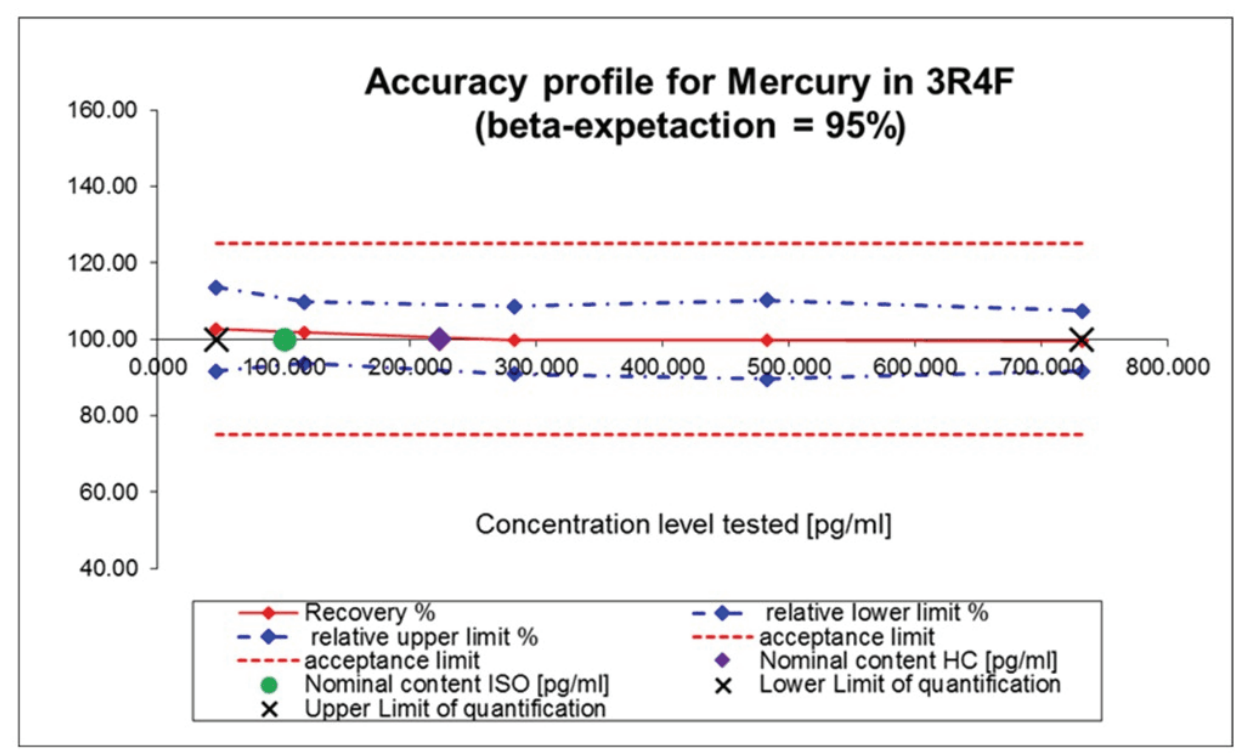

Figure 4. Plot of working range limits in $3 R 4 F(p g / m L)$.

Table 4. Recovery and working range limits for mercury in THS aerosol.

\begin{tabular}{|c|c|c|c|c|c|c|c|c|}
\hline $\begin{array}{l}\text { Mercury / } \\
\text { THS }\end{array}$ & Repetition & \begin{tabular}{|c|} 
Theoretical \\
concentration
\end{tabular} & $\begin{array}{c}\text { Measured } \\
\text { concentration }\end{array}$ & $\begin{array}{l}\text { Theoretical } \\
\text { concentration }\end{array}$ & $\begin{array}{c}\text { Measured } \\
\text { concentration }\end{array}$ & Recovery & \multicolumn{2}{|c|}{ 95\% Tolerance interval } \\
\hline Level & $(\mathrm{N})$ & $(\mathrm{pg} / \mathrm{mL})$ & $(\mathrm{pg} / \mathrm{mL})$ & (ng / item) & (ng / item) & $(\%)$ & $\begin{array}{c}\text { Lower limit } \\
(\%)\end{array}$ & $\begin{array}{c}\text { Upper limit } \\
(\%)\end{array}$ \\
\hline DIL1 & 16 & 27.88 & 29.82 & 0.56 & 0.60 & NA & 87.8 & 126.2 \\
\hline DIL2 & 16 & 44.60 & 45.48 & 0.89 & 0.91 & NA & 88.0 & 115.9 \\
\hline SP0 & 16 & 55.75 & 55.75 & 1.12 & 1.12 & NA & 90.0 & 110.0 \\
\hline SP1 & 16 & 80.73 & 80.19 & 1.61 & 1.60 & 99.34 & 90.9 & 107.8 \\
\hline SP2 & 16 & 105.70 & 105.33 & 2.11 & 2.11 & 99.65 & 92.0 & 107.3 \\
\hline SP3 & 16 & 205.60 & 202.00 & 4.11 & 4.04 & 98.25 & 92.5 & 104.0 \\
\hline \multicolumn{3}{|c|}{ Matrix HC (10 acc.) } & 52.48 & & 1.05 & & & \\
\hline \multicolumn{3}{|c|}{ Matrix ISO (20 acc.) } & 48.33 & & 0.48 & & & \\
\hline \multicolumn{3}{|c|}{ LWRL (10 acc.) } & 29.11 & & 0.58 & & & \\
\hline \multicolumn{3}{|c|}{ UWRL (10 acc.) } & 205.60 & & 4.11 & & & \\
\hline
\end{tabular}

DIL1: dilution 1, DIL2: dilution 2, SP0: matrix at nominal concentration, SP1: spike 1, SP2: spike 2, SP3: spike 3

10/20 acc.: 10/20 accumulated items per smoking run, LWRL: lower working range limit, UWRL: upper working range limit 


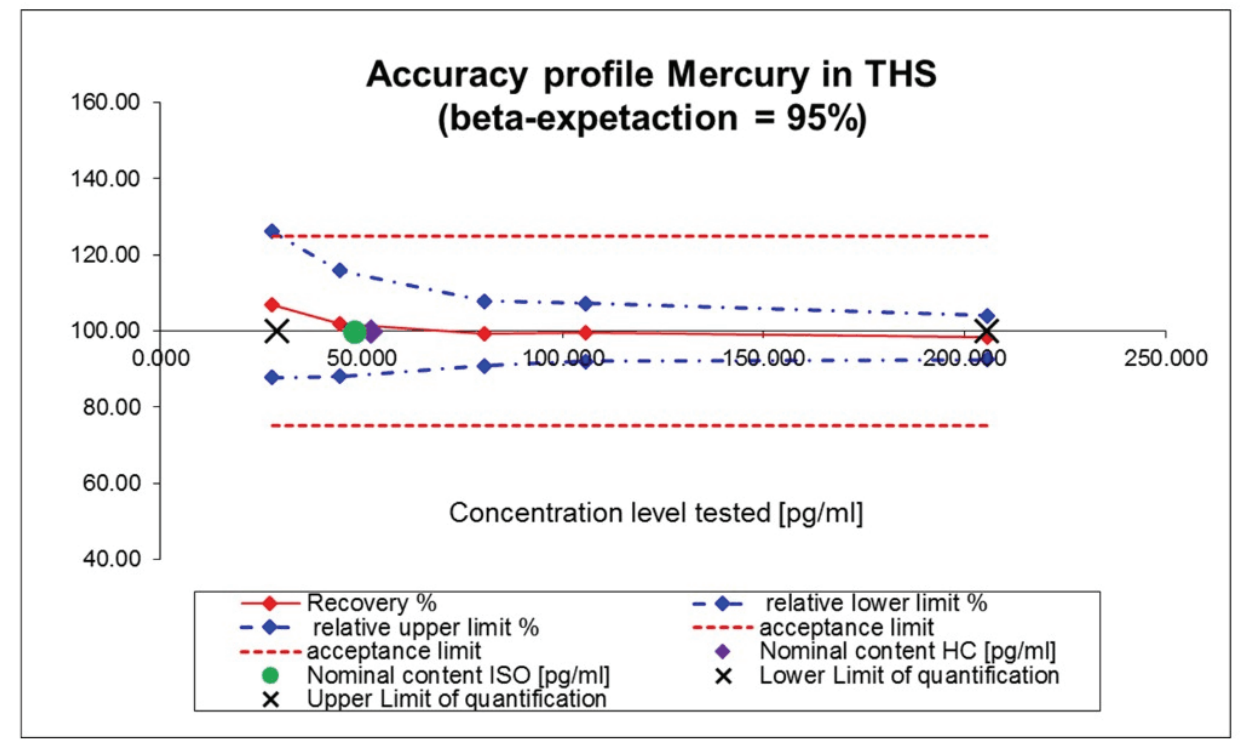

Figure 5. Plot of working range limits in THS $(\mathrm{pg} / \mathrm{mL})$.

Table 5. Comparison with mercury yield data reported by other laboratories in a CORESTA study (2) for 3R4F under HC and ISO smoking regimens.

\begin{tabular}{l|c|c|c|c|c|c|c|c}
\hline \multirow{2}{*}{$\begin{array}{l}\text { Smoking } \\
\text { regimen }\end{array}$} & \multicolumn{3}{|c|}{ Validation results } & \multicolumn{5}{c}{ CORESTA study (2) results } \\
\cline { 2 - 9 } & $\begin{array}{c}\text { Days * } \\
(\mathrm{N})\end{array}$ & $\begin{array}{c}\text { Mean } \\
(\mathrm{ng} / \mathrm{cig})\end{array}$ & $\begin{array}{c}\mathrm{CV}_{\mathrm{IP}} \\
(\%)\end{array}$ & $\begin{array}{c}\text { Data sets ** } \\
(\mathrm{N})\end{array}$ & $\begin{array}{c}\text { Mean } \\
(\mathrm{ng} / \mathrm{cig})\end{array}$ & $\begin{array}{c}\text { Lower } \\
\text { concentration } \\
(\mathrm{ng} / \mathrm{cig})\end{array}$ & $\begin{array}{c}\text { Higher } \\
\text { concentration } \\
(\mathrm{ng} / \mathrm{cig})\end{array}$ & $\begin{array}{c}\mathrm{CV}_{\mathrm{R}} \\
(\%)\end{array}$ \\
\hline $\mathrm{HC}$ & 4 & 4.5 & 7.7 & 8 & 4.9 & 4.1 & 5.7 & 12.4 \\
ISO & 3 & 2.0 & 4.7 & 7 & 2.3 & 1.8 & 3.1 & 19.8 \\
\hline
\end{tabular}

* Number of days (4 individual replicates by day; ${ }^{\star \star}$ Number of data sets (number of labs)

\section{CONCLUSIONS}

The purpose of the developed method was to quantify mercury in the gas-vapor phase of mainstream smoke of cigarettes and/or aerosol of heated tobacco from the tobacco heating system (THS) by ICP-MS. The gas-vapor phase is trapped in an acid solution and analyzed directly after sample dilution without time-consuming mineralization step.

The method was successfully validated for the quantification of mercury in the gas-vapor phase of mainstream cigarette smoke and in heated tobacco aerosol generated by a tobacco heating system (THS) under HC and ISO smoking regimens. A summary of validation results are depicted in Table 6.

It must be pointed out that validation results of this method reported in Table 6 were obtained with a calibration curve where calibration points were not equidistantly distributed (Figure 3). However, it is recommended to distribute as equidistantly as possible the various concentration levels for standards in the calibration curve to prevent points of influence and to change the validated calibration curve accordingly.
Table 6. Summary of results for the evaluated validation parameters obtained throughout the validation of the method for the quantification of mercury in 3R4F smoke and THS aerosol.

\begin{tabular}{l|ccc|c|c}
\hline \multirow{2}{*}{ Parameters } & \multicolumn{2}{|c|}{ Health Canada } & \multicolumn{2}{c}{ ISO } \\
\cline { 2 - 5 } & $\begin{array}{c}\text { 3R4F } \\
\text { (ng / cig) }\end{array}$ & $\begin{array}{c}\text { THS } \\
(\mathrm{ng} / \text { item })\end{array}$ & $\begin{array}{c}\text { 3R4F } \\
\text { (ng / cig) }\end{array}$ & $\begin{array}{c}\text { THS } \\
\text { (ng / item) }\end{array}$ \\
\hline LOD & 0.0919 & 0.0919 & 0.0919 & 0.0460 \\
LLOQ & 0.306 & 0.306 & 0.306 & 0.153 \\
ULOQ & 20.3 & 20.3 & 20.3 & 10.2 \\
LWRL & 0.930 & 0.582 & 0.930 & NA \\
UWRL & 14.6 & 4.11 & 14.6 & NA \\
STD1 & 0.500 & 0.500 & 0.500 & 0.250 \\
Nominal & 4.47 & 1.05 & 1.99 & 0.48 \\
concentration & 0.459 & 0.143 & 0.202 & 0.063 \\
r & 0.976 & 0.229 & 0.262 & 0.063 \\
IP & 0.891 & 0.193 & 0.196 & 0.016 \\
CD & & & & \\
$(95 \%, \mathrm{n}=4)$ & & &
\end{tabular}

LOD: limit of detection, LLOQ: lower limit of quantification, ULOQ: upper limit of quantification, LWRL: lower working range limit, UWRL: upper working range limit, r: repeatability, IP: intermediate precision, CD: critical difference at 95\%, NA: not applied 


\section{REFERENCES}

1. McDaniel, R.L, K.M. Torrence, D.A. Self, and M.J. Chang: Determination of Mercury in Mainstream Cigarette Smoke by Conventional and Amalgamation Cold Vapor Atomic Absorption Spectrometry; Beitr. Tabakforsch. Int. 19 (2001) 267-276.

DOI: $10.2478 /$ cttr-2013-0713

2. Purkis, S.W. and M. Intorp: Analysis of Reference Cigarette Smoke Yield Data From 21 Laboratories for 28 Selected Analytes as a Guide to Selection of New CORESTA Recommended Methods; Beitr. Tabakforsch. Int. 26 (2014) 57-73. DOI: $10.2478 / \mathrm{cttr}-2014-0010$.

3. International Conference on Harmonisation of Technical Requirements for Registration of Pharmaceuticals for Human Use (ICH): ICH Harmonized Tripartite Guideline. Validation of Analytical Procedures: Text and Methodology Q2(R1), 2005. Available at: https://www.ich.org/fileadmin/Public_Web_Site/ ICH_Products/Guidelines/Quality/Q2_R $1 /$ Step4/Q2 R1 Guideline.pdf (accessed November 2017).

4. Association of Official Agricultural Chemists (AOAC): AOAC Official Methods of Analysis Guidelines for Standard Method Performance Requirements, Appendix F.; 2002. Available at: https://www.aoac.org/aoac prod_imis/AOAC_Docs/NEWS/SMPR_Kratomv4.pdf (accessed November 2017).

5. Association Francaise de Normalisation (AFNOR): AFNOR NF V 03-110. Analysis of Agri-FoodstuffsProtocol of Characterization for the Validation of a Quantitative Method of Analysis by Construction of an Accuracy Profile; 2010. Available at: https://infostore. saiglobal.com/en-us/Standards/NFV-03-110-20101411610/ (accessed November 2017).

6. U.S. Food \& Drug Administration (FDA): Established List of the Chemicals and Chemical Compounds Identified by FDA as Harmful and Potentially Harmful Constituents in Tobacco Products and Tobacco Smoke; Federal Register, Vol. 77, No. 64, 2012. Available at: https://www.gpo.gov/fdsys/pkg/FR-2012-04-03/pdf/ 2012-7727.pdf (accessed Nov 14 2017).

7. Chang, M.J., R.L. McDaniel, J.D. Naworal, and D.A. Self: A Rapid Method for the Determination of Mercury in Mainstream Cigarette Smoke by Two-Stage Amalgamation Cold Vapor Atomic Absorption Spectrometry; J. Anal. At. Spectrom. 17 (2002) 710-715. DOI: $10.1039 / \mathrm{B} 200715 \mathrm{~K}$

8. Fresquez, M.R., N. Gonzalez-Jimenez, N. Gray, C.H. Watson, and R.S. Pappas: High Throughput Determination of Mercury in Tobacco and Mainstream Smoke from Little Cigars; J. Anal. Toxicol. 39 (2015) 545-550. DOI: 10.1093/jat/bkv069

9. Chen, J.: Determination of Mercury in Wastewater by Inductively Coupled Plasma-Mass Spectrometry; Application Note, Perkin Elmer, Inc. Shelton, CT
06484 USA. Available at: www.perkinelmer.com/pdfs/ downloads/APP_MercuryinWastewaterbyICPMS.pdf (accessed November 2017).

10. Parikh, Y., S. Mahmoud, J. Lallo, and H. Lang: Sample Preparation Method for Mercury Analysis in Reagent Chemicals by ICP-OES; Spectroscopy, Special Issues 30 (2015) 8-17. Available at: http://www.spectro scopyonline.com/sample-preparation-method-mercuryanalysis-reagent-chemicals-icp-oes (accessed November 2017).

11. Gaines, $\mathrm{P} .:$ Common Problems with $\mathrm{Hg}, \mathrm{Au}, \mathrm{Si}$, Os and Na; ICP Operations Guide: Part 12, Inorganic Ventures. Available at: https://www.inorganicventures.com/ common-problems-hg-au-si-os-and-na (accessed November 2017).

12. US Environmental Protection Agency (EPA): Mercury Preservation Techniques; Bulletin March 2003. Available at: https://www.inorganicventures.com/sites/ default/files/mercury_preservation_techniques.pdf (accessed November 2017).

13. US Environmental Protection Agency (EPA): Inductively Coupled Plasma-Mass Spectrometry; Method 6020A, Revision 1, January 1998. Available at: https:/www.epa.gov/sites/production/files/201507/documents/epa-6020a.pdf (accessed November 2017).

14. British American Tobacco Group Research \& Development: Method - Determination of Metals in Mainstream Cigarette Smoke; March 2008. Available at: http://www.bat-science.com/groupms/sites/bat 9gvjxs.nsf/vwPagesWebLive/DO7AXGCL/\$FILE/ medMD7DAEAM.pdf?openelement (accessed November 2017).

15. Smith, M.R., B. Clark, F. Lüdicke, J.P. Schaller, P. Vanscheeuwijck, J. Hoeng, and M.C. Peitsch: Evaluation of the Tobacco Heating System 2.2. Part 1: Description of the System and the Scientific Assessment Program; Regul. Toxicol. Pharmacol. 81 (2016) S17-S26. DOI: 10.1016/j.yrtph

16. University of Kentucky: Kentucky Tobacco Research \& Development Center, Center for Tobacco Reference Products; Lexington, KY, USA. Available at: www.uky.edu/KTRDC/ (accessed November 2017).

Corresponding author:

Iris Hofer

Philip Morris International Research and Development

Philip Morris Product SA

Quai Jeanrenaud 5

2000 Neuchâtel

Switzerland

E-mail:Iris.Hofer@pmi.com 